\title{
Assessment of Risk Due to Chemicals Transferred in a Watershed: A Case of an Aquifer Storage Transfer and Recovery Site
}

\author{
Hyon Wook Ji and Sang-Il Lee * \\ Department of Civil and Environmental Engineering, Dongguk University, 30, Pildong-ro 1-gil, Jung-gu, \\ Seoul 04620, Korea; mousehw@naver.com \\ * Correspondence: islee@dongguk.edu; Tel.: +82-2-2260-3353
}

Academic Editors: Joan M. Brehm and Brian W. Eisenhauer

Received: 17 March 2016; Accepted: 1 June 2016; Published: 4 June 2016

\begin{abstract}
This paper presents an analysis of the potential risks of chemicals that can affect an aquifer storage transfer and recovery (ASTR) site. ASTR is a water supply system that injects surface water into an aquifer and then extracts naturally filtered groundwater. The pilot site of the ASTR supplying drinking water is located downstream of the Nakdong River in South Korea. Hazard analysis and critical control points (HACCP) was adopted to ensure suitable water quality in response to the deteriorated water quality of the Nakdong River. HACCP is a proactive management system for ensuring consistent confidence in food (or water). Hazard analysis, the first of the seven principles of HACCP, assesses physical, microbial, chemical, and radioactive hazards. This study focuses on the chemicals that are most likely to be involved in major hazardous events. Pollutant release and transfer register (PRTR) data were used to analyze potential risks of chemicals. A PRTR is a national environmental database of potentially hazardous chemicals. Potential risk analysis considers the total amount of chemicals transferred off-site for treatment or disposal. Fifty-five cities and the top 10 chemicals released in the Nakdong River basin were investigated. Potential risk was defined as a function of total transfers, the relative distance, and toxicity. The top 10 cities with high potential risks were identified, and the city with the highest potential risk turned out to be Ulju.
\end{abstract}

Keywords: drinking water; HACCP; chemical hazard; aquifer storage transfer and recovery; pollutant release and transfer register

\section{Introduction}

As water resources planning and management become a global issue, South Korea is also promoting relevant projects to meet the challenges from environmental pollution and climate change. The Nakdong River, one of the largest rivers in the country, is a major drinking water source for more than ten million people. The water quality of the Nakdong River has been deteriorated due to routine emission and spills of chemicals. According to a consumer survey in South Korea [1], 32.5\% of respondents do not drink tap water because they have concerns about raw water quality even though purification process of the tap water complies with the drinking water guideline. Hence, there is presently a heightened need to improve drinking water quality and protect raw water from pollution. This paper deals with an effort in which aquifer storage transfer and recovery (ASTR) is combined with hazard analysis and critical control points (HACCP) to satisfy the needs for better drinking water quality.

ASTR can be an alternative to the direct intake from the surface source for drinking water production, and is an enhanced method to improve drinking water quality [2,3]. ASTR is a method to store surface water in an aquifer through an injection well and to employ the water through an 
extraction well (Figure 1). Water injected into an aquifer is purified naturally by soil particles and indigenous microorganisms. Injection and extraction of water can be performed simultaneously, thereby ensuring a continuous water supply. In addition, the depletion of an aquifer and ground subsidence can be significantly reduced.

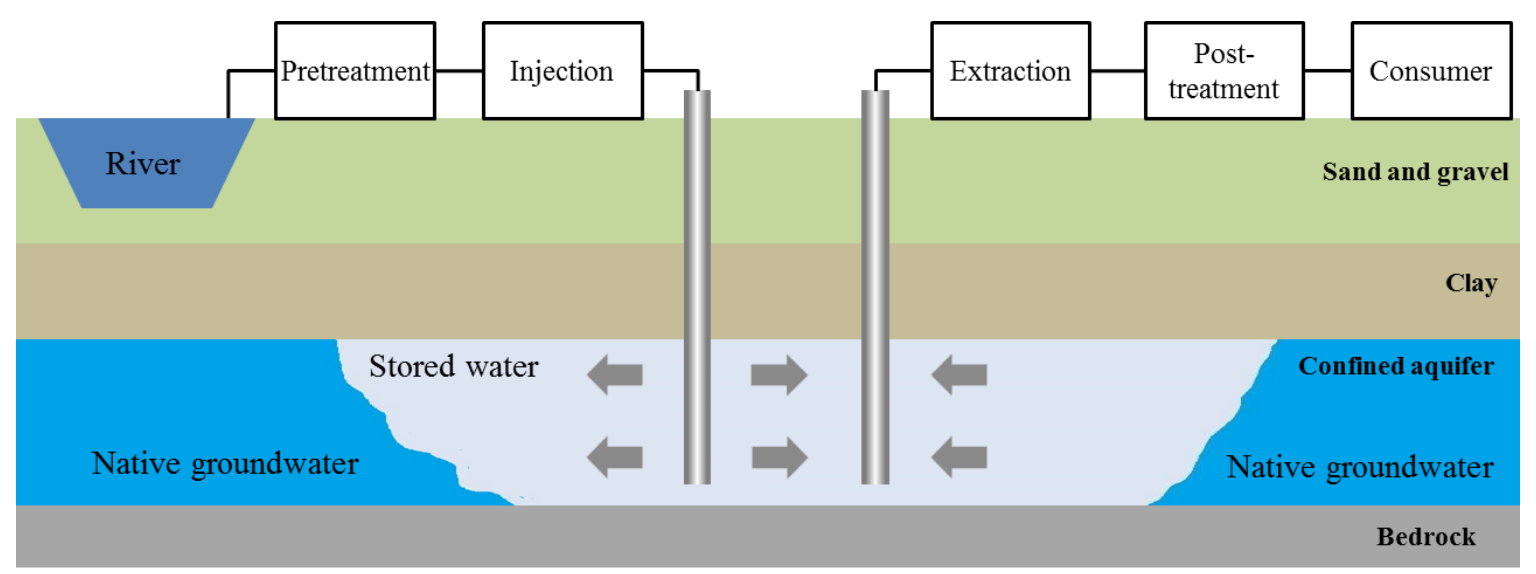

Figure 1. Schematic representation of drinking water production process using ASTR.

Pretreatment is necessary to control water quality of the injected water to avoid well clogging and contamination of the aquifer as it could lead to some environmental problems. To prevent these problems, some countries have strong guidelines [4,5]. After the injection and extraction in the ASTR, the water is distributed to the consumer through the supply process including post-treatment, storage tanks, and distribution network. The water can be contaminated by internal and external hazards during the supply process as well. HACCP is implemented to control all these hazards.

HACCP can protect and control the water quality in the entire process of drinking water supply. An increasing number of cases is being reported that HACCP is incorporated to drinking water production [6-9]. Since HACCP analyzes and controls hazards from the watershed to the consumer, proactive prevention of risks is feasible. Lee and Ji [10] analyzed hazards that exist in all processes of drinking water production using ASTR. They found 114 hazardous events, and nine out of those 114 hazardous events were major (Table 1). Seven out of nine major hazardous events turned out to occur in watersheds, not in the purification facility. They also discovered that eight out of the major events were related with toxic chemicals. The fact indicated that most major hazards could be eliminated, if the chemicals generated in the watersheds were carefully managed.

In conventional water supply systems, there is no right to control chemical accidents happening upstream. Therefore, the purification facility has no choice but to stop supplying water when accidents occur. Here, potential risk assessment was designed to solve the problem.

The objective of the present study is to develop a quantitative method to evaluate potential risks of chemical substances transferred in a watershed. Risk, generally expressed by product of damage and uncertainty [11], can be extensively applied to various situations for various purposes. For instance, there can be the effects on human health, the loss of asset, the destruction of building, or leakage of substances, etc. In the case of human health, risk of leakage of carbon dioxide in Carbon Capture and Storage [12], chemical risk [13], ecological risk [13], microbial risk [13-15], risk associated with hazards of drinking water to human health [16], etc., were studied. The present study deals with potential risk to a drinking water supply facility by chemicals in a watershed. The approach does not directly express risk, but it assesses the potential of risk.

The results of potential risk assessment are prioritized for preemptive management of chemicals to reduce the risk. Potential risk can be a basis to establish a cooperative relationship between cities and ASTR site to supply the safer water. This study will strengthen the first phase of HACCP (i.e., "perform hazard analysis"), as shown in Figure 2. 
Table 1. Major hazardous events in the process of drinking water production [10].

\begin{tabular}{|c|c|c|c|}
\hline Process & Hazardous Event & Type $^{1}$ & Hazards \\
\hline \multirow{7}{*}{$\begin{array}{l}\text { Catchment } \\
\text { Area }\end{array}$} & $\begin{array}{l}\text { Illegal release of waste water from } \\
\text { restaurants and private waste water } \\
\text { treatment plants }\end{array}$ & $\mathrm{M}, \mathrm{C}$ & $\begin{array}{l}\text { Pathogens, nutrients, } \\
\text { surfactants, metal, heavy metal, } \\
\text { non-biodegradable organics, } \\
\text { color, odor, taste }\end{array}$ \\
\hline & $\begin{array}{l}\text { Discharge of waste water from factories in } \\
\text { the upstream }\end{array}$ & $\mathrm{C}$ & $\begin{array}{l}\text { Metal, heavy metal, } \\
\text { non-biodegradable organics }\end{array}$ \\
\hline & $\begin{array}{l}\text { Release by accidents of major chemicals } \\
\text { from industrial complex }\end{array}$ & $\mathrm{C}$ & Non-biodegradable organics \\
\hline & Frequent oil leakage accidents & $\mathrm{C}$ & Non-Aqueous Phase Liquids (NAPLs) \\
\hline & Land use & $\mathrm{M}, \mathrm{C}, \mathrm{P}$ & $\begin{array}{l}\text { Pathogens, sulfur oxides, nutrients, } \\
\text { turbidity, color, surfactants, organic } \\
\text { matter, oil-contaminant }\end{array}$ \\
\hline & $\begin{array}{l}\text { Rapid change of river water quality by } \\
\text { flood and drought }\end{array}$ & $\mathrm{M}, \mathrm{C}$ & $\begin{array}{l}\text { Pathogens, nutrients, turbidity, color, } \\
\text { algae, toxic material, odor, taste }\end{array}$ \\
\hline & Year-round occurrence of eutrophication & $\mathrm{M}, \mathrm{C}$ & $\begin{array}{l}\text { Algae, toxic material, } \\
\text { color, odor, taste }\end{array}$ \\
\hline Storage & $\begin{array}{l}\text { Rapid growth of cyanobacteria by } \\
\text { abnormal high temperature in storage tank }\end{array}$ & M & Algae \\
\hline $\begin{array}{l}\text { Storage of } \\
\text { treated water }\end{array}$ & $\begin{array}{l}\text { Regrowth of pathogens or carcinogen } \\
\text { (THMs) by inappropriate maintenance of } \\
\text { residual chlorine }\end{array}$ & $\mathrm{C}$ & Pathogens, disinfection by-products \\
\hline
\end{tabular}

Note: ${ }^{1}$ M: Microbial, C: Chemical, P: Physical.

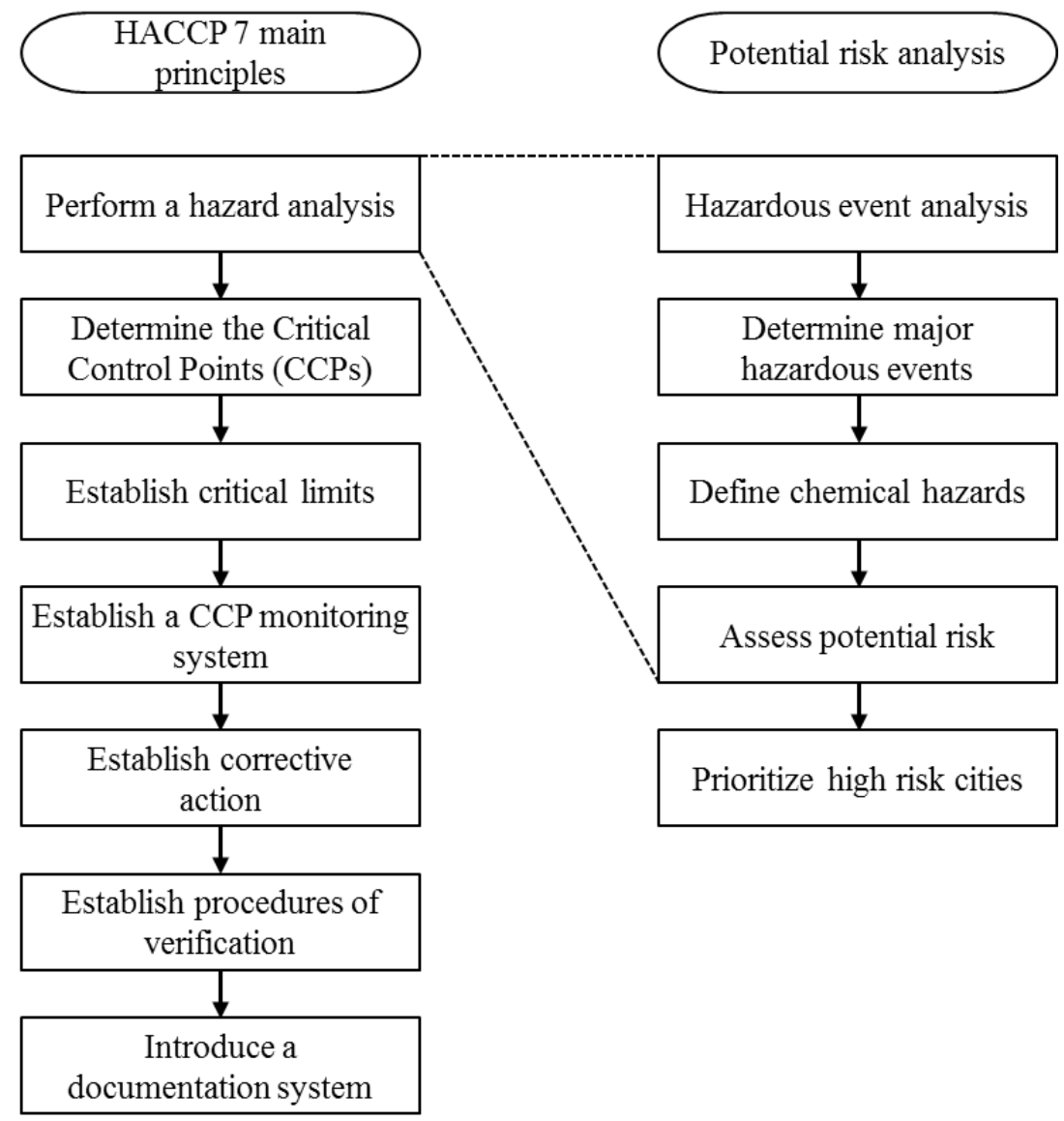

Figure 2. Relationship of hazard analysis and critical control points (HACCP) 7 principles and potential risk analysis. 


\section{Materials and Methods}

\subsection{Study Area}

The drinking water production facility using ASTR is located in the delta of the Nakdong River in South Korea (Figure 3). Surrounding cities have suffered from water quality degradation of the Nakdong River. ASTR has been adopted as a measure to resolve the water quality issues.

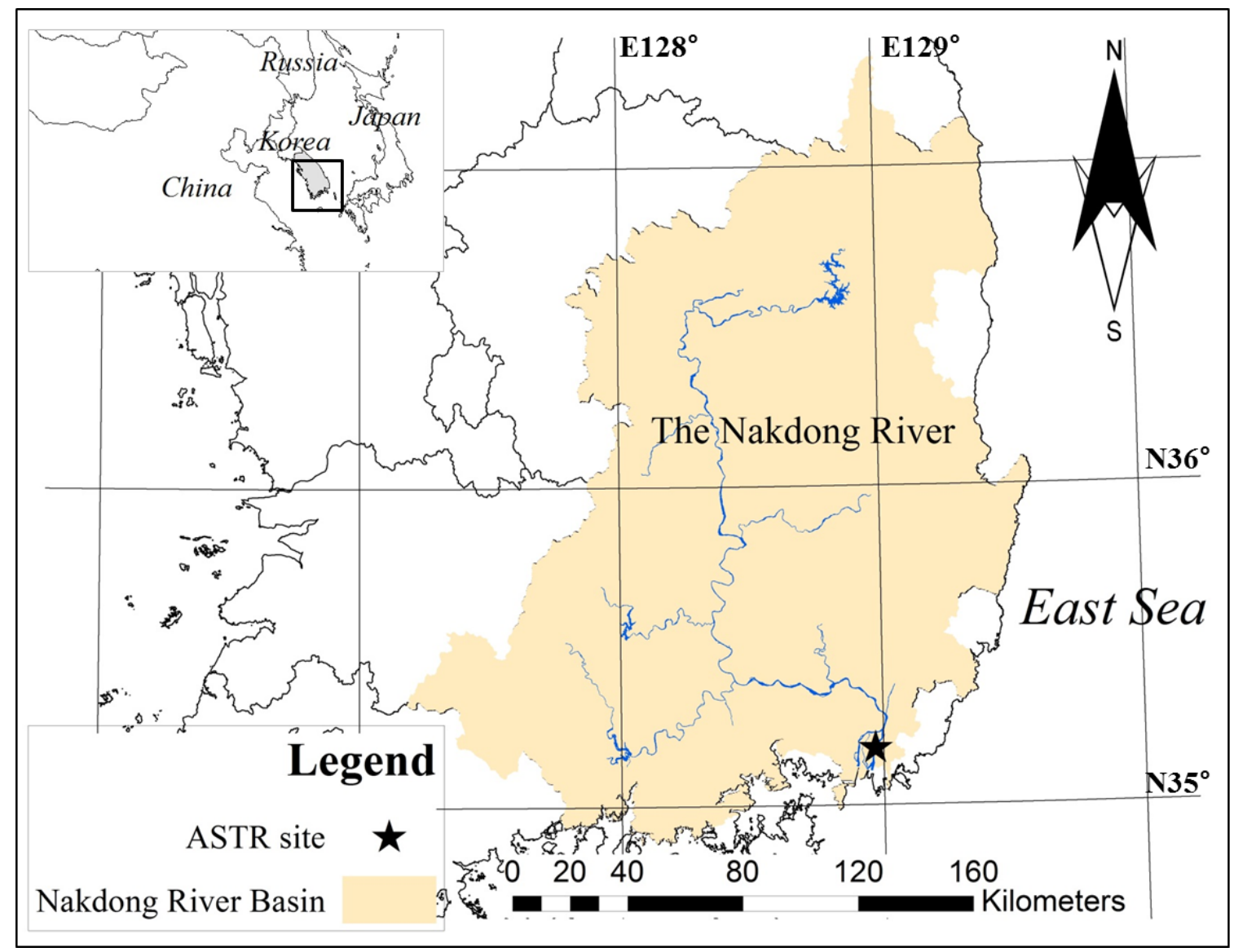

Figure 3. Study area (the Nakdong River Basin).

The facility aims at $2000 \mathrm{~m}^{3}$ /day of water production and 1,000,000 $\mathrm{m}^{3}$ of storage in the aquifer. Surface water is taken and pre-treated before injection. As shown in Figure 1, water injected into the confined aquifer pushes out saltwater and forms a freshwater body. The injected water travels through the aquifer and is purified naturally by soil particles and indigenous microbes [17-19]. The extracted water is supplied to consumers through the existing purification plant.

Since the ASTR site is located at the mouth of the Nakdong River, chemicals discharged deliberately or accidentally to the environment in the basin ultimately pass through the site. The basin has previously experienced serious water quality degradation due to chemical leaks [20]. Therefore, it is necessary to analyze the potential risk from chemicals used in the basin in order to supply high quality drinking water in a reliable manner and to prevent from possible chemical-related accidents. The Nakdong River basin consists of 55 cities and, for convenience of analysis, we assigned a number to each city, as shown in Figure 4. 


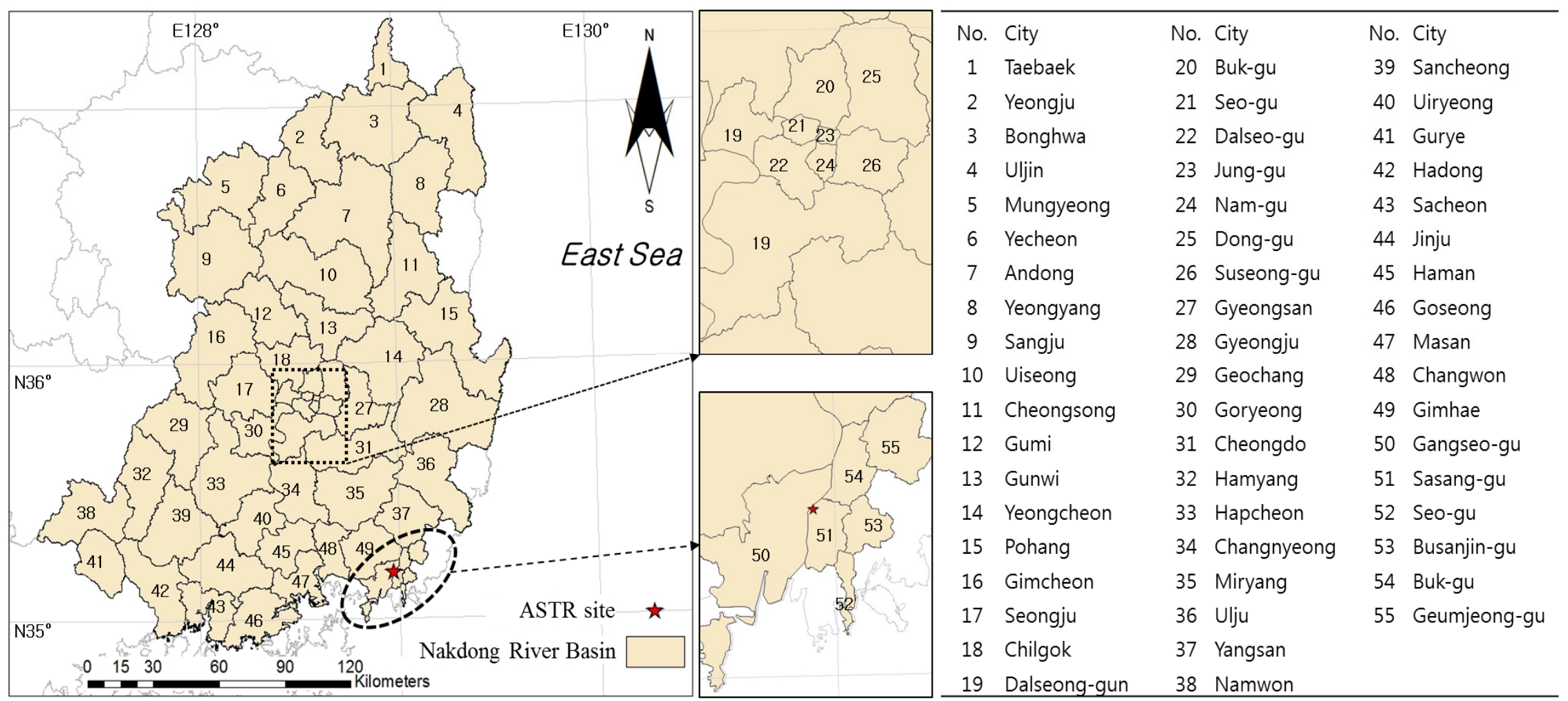

Figure 4. Cities in the Nakdong River Basin. 


\subsection{Pollutant Release and Transfer Register (PRTR)}

The pollutant release and transfer register (PRTR) provides emission sources and amounts of chemical substances released from a city. The PRTR publicly discloses voluntarily released data that identifies and reports amounts of chemical substances emitted from each firm, as shown in Figure 5. The aim of the PRTR is to induce voluntary reductions in emissions of chemical substances [21]. The disclosure strategy of the PRTR has been evaluated as strong and cost-effective environmental monitoring. Due to this advantage, the U.S. Environmental Protection Agency (EPA) has considered the PRTR to be one of the most valuable tools in protecting human health and the environment [22].

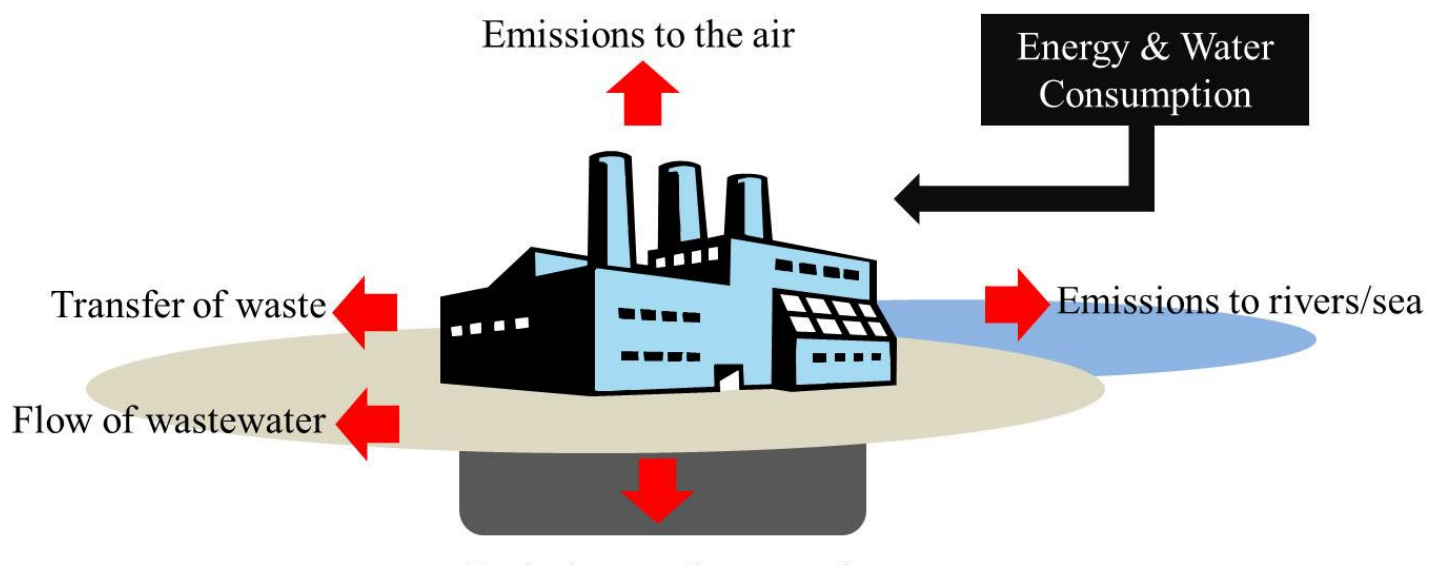

Emissions to the ground

Figure 5. Emission and transfer information of chemicals PRTR provides (modified from [23]).

The PRTR was first adopted in the Netherlands in 1976 and was later adopted in the United States as the Toxics Release Inventory (TRI), which has significantly contributed to reductions in emissions of harmful chemicals [24]. In South Korea, investigations into toxic releases by the Ministry of Environment in Korea have been conducted since 1999 and official reports have been published since 2002. As of 2011, 415 chemicals were designated as watch list chemicals, the number of actual reported chemicals was 242, and the number of firms that reported chemical releases was 3159 [25].

The PRTR provides two types of data: the emission that represents the amount of chemicals discharged to water systems, the atmosphere, and soils; and the transfer that represents the amount of chemicals transferred to either external treatment companies or public wastewater treatment facilities [26]. Although the emissions influence the environment directly, onsite emission regulations are enforced according to environmental laws. Thus, concentrations of emitted substances would be relatively low, resulting in minimal environmental damage from a short- and midterm perspective. On the other hand, concentrations and toxicity of transferred chemicals will be relatively high. If an accident were to occur during transfer, irreversible damage to nature could be done. Thus, the present study considered a transfer as a potential hazard of chemical-related accidents, thereby analyzing the potential risk of total transfers to drinking water production facilities using ASTR.

\subsection{Chemicals for Analysis}

From PRTR information published from 2001 to 2012, top 10 chemicals discharged to the Nakdong River basin were selected for analysis (Table 2). Xylene and toluene are used in many products including adhesives, inks, and thinners. Other chemicals are also used as basic raw material of many products such as cosmetics, solvents, catalysts, and dyes.

For toxicity, the NFPA 704 index was used. NFPA 704 is a standard maintained by the U.S. National Fire Protection Association, which shows the risks for flammability, health, reactivity, and 
special notices posed by hazardous materials [27]. The risks range from 0 (low) to 4 (high). The index on health is used to determine the potential risk.

Table 2. Top ten chemicals released in the Nakdong River Basin in 2011 and toxicity.

\begin{tabular}{ccccc}
\hline Rank & Chemical & CAS No. ${ }^{\mathbf{1}}$ & Molecular Formula & Toxicity $^{\mathbf{2}}$ \\
\hline 1 & Xylene & $1330-20-7$ & $\mathrm{C}_{8} \mathrm{H}_{10}$ & 2 \\
2 & Toluene & $108-88-3$ & $\mathrm{C}_{7} \mathrm{H}_{8}$ & 2 \\
3 & Dichloromethane & $75-09-2$ & $\mathrm{CH}_{2} \mathrm{Cl}_{2}$ & 2 \\
4 & Methyl alcohol & $67-56-1$ & $\mathrm{CH}_{3} \mathrm{OH}$ & 1 \\
5 & Ethyl acetate & $141-78-6$ & $\mathrm{C}_{4} \mathrm{H}_{8} \mathrm{O}_{2}$ & 1 \\
6 & Methyl ethyl ketone & $78-93-3$ & $\mathrm{CH}_{3} \mathrm{COC}_{2} \mathrm{H}_{5}$ & 1 \\
7 & Isopropanol & $67-63-0$ & $\mathrm{C}_{3} \mathrm{H}_{8} \mathrm{O}$ & 1 \\
8 & Ethylbenzene & $100-41-4$ & $\mathrm{C}_{6} \mathrm{H}_{5} \mathrm{C}_{2} \mathrm{H}_{5}$ & 2 \\
9 & $N, N$-Dimethylformamide & $68-12-2$ & $\mathrm{HCON}\left(\mathrm{CH}_{3}\right)_{2}$ & 1 \\
10 & Trichloroethylene & $79-01-6$ & $\mathrm{C}_{2} \mathrm{HCl}_{3}$ & 2 \\
\hline Notes: ${ }^{1}$ Chemical Abstract Service Registry Number; ${ }^{2}$ Index about health by National Fire Protection \\
Association. Low (0)-high (4); Source: [28].
\end{tabular}

\subsection{Mathematical Formulation}

We considered that PRTR data, distance, and toxicity are related to both the scale of damage by chemical accidents and the probability of chemical accidents. According to this basic premise, the function of potential risk is constituted by three components of total transfer, distance, and toxicity. The three components are defined below.

The total transfer provides the quantity of chemicals transferred per city. The total transfer can be calculated by using Equation (1).

$$
I_{q c}^{t}=\frac{x_{q c}^{t}-\min \left(x_{q}^{t_{0}}\right)}{\max \left(x_{q}^{t_{0}}\right)-\min \left(x_{q}^{t_{0}}\right)}
$$

where, $I_{q c}^{t}$ is relative transfer at a specific chemical, city, and time as a dimensionless number [29], $x_{q c}^{t}$ is amount of chemical transferred, $t$ is time, $t_{0}$ is reference time, $q$ represents chemical type, and $c$ represents city. Equation (1) can consider time change by evaluation of transfer amount based on $t_{0}$. Equation (2) shows a total amount of $\mathrm{I}_{\mathrm{qc}}$ over time.

$$
I_{q c}=\sum_{t=1}^{n} I_{q c}^{t}
$$

$\mathrm{I}_{\mathrm{qc}}$ refers to the sum of relative transfer of chemicals over time and $\mathrm{n}$ represents the number of years of the chemical transfer data.

The amount of chemicals is reduced as they are transferred due to adsorption and evaporation. Therefore, a distance between the ASTR site and chemical discharge is one of the key factors that determine the risk from chemicals. The farther the discharge site from the ASTR site is, the lower the potential risk posed by chemicals becomes. Reversely, the closer the discharge site to the ASTR site, the higher the chemical risk. Thus, a distance can be represented as shown in Equation (3).

$$
D_{c}=\frac{\max (d)-d_{c}}{\max (d)-\min (d)}+1
$$

$D_{c}$ refers to the relative distance and $d$ is, the distance between the location of interest and the centroid of a city, which can be calculated using a GIS tool. Subscript c represents a specific city. The reason for adding 1 in the formula is because potential risk cannot be 0 no matter how far the distance is. According to this formula, $\mathrm{D}_{\mathrm{c}}$ ranges from 1 to 2 . The closer the discharge location is to the location of interest, the closer $D_{c}$ is to 2 . The farther the discharge location is, the closer $D_{c}$ is to 1 . The relative 
distance combined with the relative transfer of chemicals can be represented as a potential risk of the chemical in each city, as shown in Equation (4).

$$
R_{q c}=\sqrt{\sum_{t=1}^{n} I_{q c}^{t} \times h_{q} \times D_{c}}
$$

$\mathrm{R}_{\mathrm{qc}}$ refers to the potential risk of chemicals in each city, and $h$ is toxicity of a chemical as defined by the health risk index of NFPA 704, as shown in Table 2. Equation (5) can evaluate the potential risk for all chemicals. In addition, Equation (5) incorporates toxicity.

$$
R_{c}=\sqrt{\frac{\sum_{q=1}^{m}\left(\sum_{t=1}^{n} I_{q c}^{t} \times h_{q}\right) \times D_{c}}{\sum_{q=1}^{m} h_{q}}}
$$

$R_{c}$ refers to the potential risk of all the chemicals in each city. $m$ refers to the number of chemicals, and $n$ refers to the number of total years for measured data. The potential risk posed by all the chemicals from a city is assumed as the weighted sum of potential risk of each chemical. Here, toxicity acts as a weighting factor. A square root plays a role in reducing the extreme value by narrowing a range of potential risk.

If $I_{q c}^{t}$ is used instead of $\sum_{t=1}^{n} I_{q c}^{t}$ an in Equation (5) to focus on a specific time, the yearly change in potential risk can be determined as shown in Equation (6).

$$
R_{c}^{t}=\sqrt{\frac{\sum_{q=1}^{m} I_{q c}^{t} \times h_{q} \times D_{c}}{\sum_{q=1}^{m} h_{q}}}
$$

\section{Results and Discussion}

A relative transfer of each chemical $\left(I_{q c}\right)$ was obtained using Equation (2) with the incorporation of total transfer data from 2001 to 2012 with regards to 10 chemicals in 55 cities (Table 3). Generally speaking, coastal cities in the southeast had a relatively large amount of transfer. There, many industrial complexes are located along the coastline of the Nakdong River basin. The ranking of cities based on the $I_{q c}$ values in Table 3 speaks for such an industrial background.

The potential risk $\left(R_{q c}\right)$ of each chemical was assessed using Equation (4) (Table 3). $\mathrm{I}_{\mathrm{qc}}$ and $R_{\mathrm{qc}}$ appeared to be the same in most cities. However, if $\mathrm{D}_{\mathrm{c}}$ of a lower ranked city of $\mathrm{I}_{\mathrm{qc}}$ is larger than high rank, $\mathrm{R}_{\mathrm{qc}}$ ranking can be changed like in the case of city 28 and 37 of xylene. The most frequently high ranked cities were city 36 (Ulju) and 12 (Gumi). City of Ulju (No. 36) had a high potential risk from nine of the 10 chemicals, save for $N, N$-Dimethylformamide while city of Gumi (No. 12) had a high potential risk from six chemicals-toluene, trichloroethylene, ethyl acetate, methyl ethyl ketone, methyl alcohol, and isopropanol. Notice that four out of six chemicals transferred from Gumi (No. 12) had relatively low toxicity. This fact would affect the comprehensive potential risk $\left(R_{c}\right)$, which accounts for toxicity of chemicals.

Next, the comprehensive potential risk $\left(R_{c}\right)$ of all chemicals was analyzed. To see a change in potential risk over time, the time of PRTR inventory $(n)$ was divided into three periods: four years (2001 2004), eight years (2001 2008), and twelve years (2001 2012). The results are shown in Figure 6, which gives geologic information of the distribution. The variation becomes much larger while the potential risk is accumulated over time. The maximum values in (a), (b), and (c) are 2.31, 4.34, and 12.32 when the minimum value is always zero. Especially, the difference between $(b)$ and $(c)$ is serious. It seems that industries increased during this time gap. The potential risk caused by cities close to the 
coast was relatively high: Cities in the coastal regions (city 36, 37, 48) posed higher potential risk to ASTR site than inland cities. City 12 (Gumi) is the only exception. Special attention must be paid to cities whose recent potential risk was ranked low but their past potential risk was high.

Table 3. Relative transfer $\left(\mathrm{I}_{\mathrm{qc}}\right)$ and potential risk $\left(\mathrm{R}_{\mathrm{qc}}\right)$ of each chemical from 2001 to 2012.

\begin{tabular}{cccccc}
\hline \multirow{2}{*}{ Chemical } & \multicolumn{5}{c}{ The Ranking of Cities Based on $\mathbf{I}_{\mathbf{q c}}$ and $\mathbf{R}_{\mathbf{q c}}$} \\
\cline { 2 - 6 } & $\mathbf{1}$ & $\mathbf{2}$ & $\mathbf{3}$ & $\mathbf{4}$ & $\mathbf{5}$ \\
\hline \multirow{2}{*}{ Xylene } & $36^{1}\left(52.1^{2}\right)$ & $48(26.7)$ & $28(11.1)$ & $37(10.6)$ & $15(9.33)$ \\
& $36^{3}\left(13.7^{4}\right)$ & $48(10.0)$ & $37(6.35)$ & $28(6.08)$ & $50(6.04)$ \\
\hline \multirow{2}{*}{ Toluene } & $50(4.49)$ & $21(2.80)$ & $12(2.28)$ & $45(1.70)$ & $36(1.66)$ \\
& $50(4.21)$ & $21(3.01)$ & $12(2.56)$ & $45(2.46)$ & $36(2.45)$ \\
\hline \multirow{2}{*}{ Dichloromethane } & $45(22.3)$ & $48(5.10)$ & $44(3.25)$ & $36(2.50)$ & $37(1.63)$ \\
& $45(8.91)$ & $48(4.37)$ & $44(3.29)$ & $36(3.01)$ & $37(2.49)$ \\
\hline \multirow{2}{*}{ Methyl alcohol } & $45(11.0)$ & $12(10.1)$ & $36(9.62)$ & $19(5.06)$ & $44(4.83)$ \\
& $45(4.43)$ & $36(4.27)$ & $12(3.81)$ & $49(3.07)$ & $19(2.90)$ \\
\hline \multirow{2}{*}{ Ethyl acetate } & $12(104)$ & $36(85.9)$ & $45(33.2)$ & $37(18.9)$ & $50(11.7)$ \\
& $36(12.5)$ & $12(12.2)$ & $45(7.69)$ & $37(6.00)$ & $50(4.80)$ \\
\hline \multirow{2}{*}{ Methyl ethyl ketone } & $12(11.0)$ & $36(6.95)$ & $37(4.09)$ & $15(3.39)$ & $18(2.53)$ \\
& $12(3.97)$ & $36(3.55)$ & $37(2.79)$ & $15(2.28)$ & $50(2.07)$ \\
\hline \multirow{2}{*}{ Isopropanol } & $12(80.1)$ & $37(10.1)$ & $48(7.72)$ & $36(4.40)$ & $45(4.32)$ \\
& $12(10.7)$ & $37(4.37)$ & $48(3.80)$ & $36(2.82)$ & $45(2.77)$ \\
\hline \multirow{2}{*}{ Ethylbenzene } & $36(514)$ & $48(151)$ & $19(69.4)$ & $37(56.6)$ & $28(56.0)$ \\
& $36(43.2)$ & $48(23.8)$ & $19(15.2)$ & $37(14.7)$ & $28(13.7)$ \\
\hline \multirow{2}{*}{$N, N$-Dimethylformamide } & $20(7.03)$ & $50(5.68)$ & $27(4.02)$ & $19(1.80)$ & $16(1.69)$ \\
& $20(3.36)$ & $50(3.35)$ & $27(2.60)$ & $19(1.73)$ & $16(1.56)$ \\
\hline \multirow{2}{*}{ Trichloroethylene } & $19(4.94)$ & $36(4.60)$ & $12(1.72)$ & $27(1.35)$ & $48(1.28)$ \\
& $36(4.08)$ & $19(4.05)$ & $12(2.22)$ & $48(2.20)$ & $27(2.13)$ \\
\hline \multirow{2}{*}{${ }^{1}$ City }
\end{tabular}

Notes: ${ }^{1}$ City number; ${ }^{2}$ Value of $\mathrm{I}_{\mathrm{qc}} ;{ }^{3}$ City number; ${ }^{4}$ Value of $\mathrm{R}_{\mathrm{qc}} ;$ Note: bold font highlights the most frequently high ranked cities.

Table 4 lists the top 10 cities whose potential risk was high in cumulative times of 4, 8, and 12 years. Rankings have changed over time. In particular, the top rank has changed from city 37 (Yangsan) to 48 (Chanwon) and then, to 36 (Ulju). Yangsan (No. 37) was the top ranked city during 2001 2004 but its ranking has fallen to the third over time. Ulju (No. 36) was the second ranked city during 2001 2004 but its rank is number one over the period of 2001 2012. The difference of city 36 between (a) and (c) is 10.28 .

Ulju (No. 36) and Yangsan (No. 37) have been on the top 3 ever since 2001. City of Changwon (No. 48) has emerged since 2005. Gumi (No. 12) became fourth (from third in early 2000s) ranked over time. This change can be interpreted as a result of low toxicity chemicals from the city and the rapid increase in potential risk of other cities.

For the top five cities $(36,48,37,12$, and 19 of the third column in Table 4 (c)), the change in annual potential risk $\left(R_{c}^{t}\right)$ was calculated using Equation (6). As can be seen in Figure 7, the potential risk of five cities in the 2000s was comparable to each other, but since 2007, the potential risk of city No. 36 (Ulju) and No. 48 (Chanwon) increased. Especially, the potential risk of Ulju increased sharply in 2011, indicating that the transfer of chemicals was increased in that year. To verify this result, original transfer data of 10 chemicals in Ulju were carefully investigated. It was found out that the reason for the sudden increase in the potential risk was largely attributable to ethylbenzene: the transfer of ethylbenzene in this city was in the order of $10^{3} \mathrm{~kg} /$ year in the past but it increased significantly in 2011 to the order of $10^{5} \mathrm{~kg}$ /year. It can be said that the annual potential risk $\left(R_{c}^{t}\right)$ gives the clue about the priority of measures to take in reducing potential risks to the facility to be protected: Monitoring and safe management of ethylbenzene of Ulju in this case. 

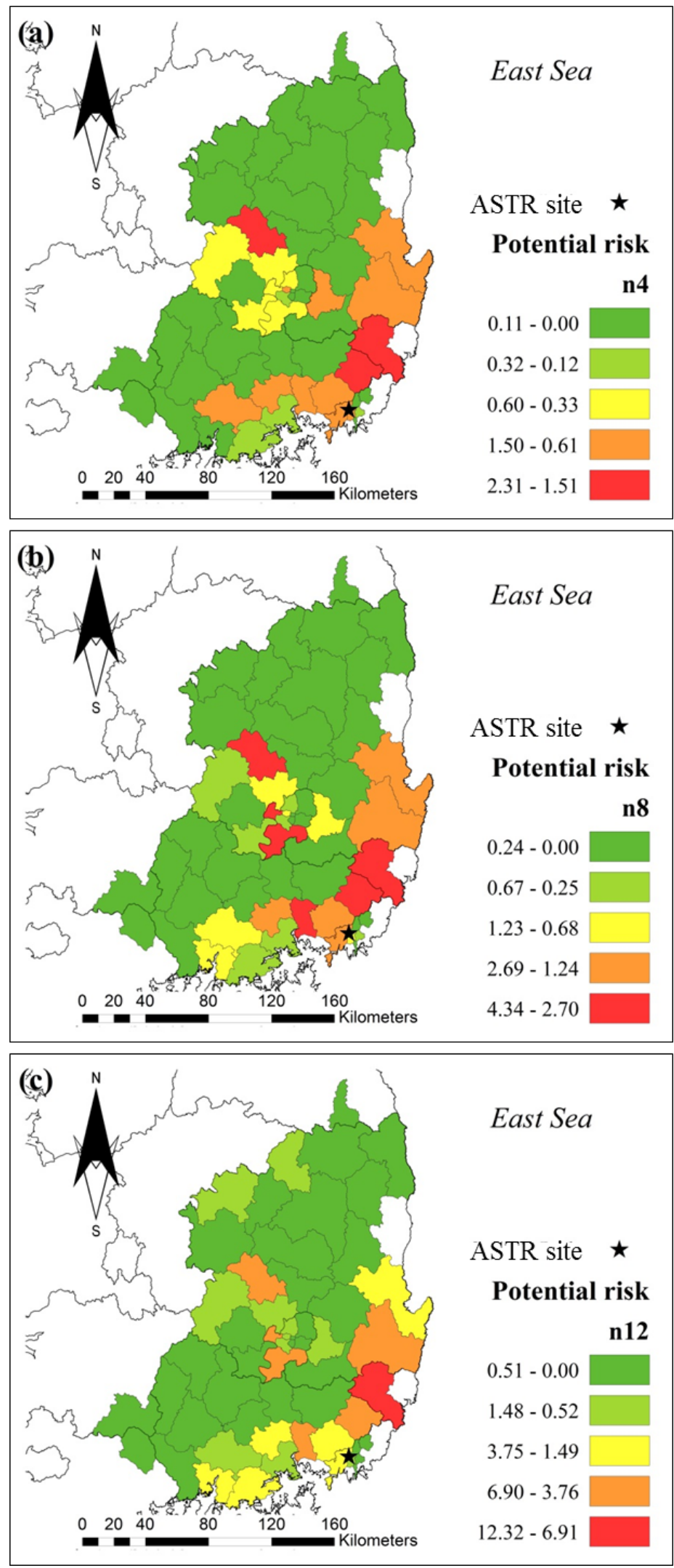

Figure 6. Potential risk $\left(\mathrm{R}_{\mathrm{c}}\right)$ of cities in the Nakdong River Basin. (a) $n=4$ years (2001 2004); (b) $n=8$ years (2001 2008); (c) $n=12$ years (2001 2012). 
Table 4. The ranking table of potential risk $\left(\mathrm{R}_{\mathrm{c}}\right)$ of cities in the Nakdong River Basin.

\begin{tabular}{ccccccc}
\hline \multirow{2}{*}{ Rank } & \multicolumn{2}{c}{$\mathbf{( a )}^{\mathbf{1}}$} & \multicolumn{2}{c}{$\mathbf{( b )}^{\mathbf{2}}$} & \multicolumn{2}{c}{$\mathbf{( c )}^{\mathbf{3}}$} \\
\cline { 2 - 7 } & City No. & $\boldsymbol{R}_{\boldsymbol{c}}$ & City No. & $\boldsymbol{R}_{\boldsymbol{c}}$ & City No. & $\boldsymbol{R}_{\boldsymbol{c}}$ \\
\hline 1 & 37 & 2.31 & 48 & 4.34 & 36 & 12.3 \\
2 & 36 & 2.15 & 36 & 4.31 & 48 & 6.90 \\
3 & 12 & 2.02 & 37 & 3.66 & 37 & 4.73 \\
4 & 48 & 1.50 & 19 & 3.57 & 12 & 4.64 \\
5 & 50 & 1.27 & 12 & 3.48 & 19 & 4.38 \\
6 & 49 & 1.19 & 45 & 2.69 & 28 & 4.03 \\
7 & 15 & 1.12 & 15 & 1.89 & 45 & 3.75 \\
8 & 45 & 1.12 & 50 & 1.69 & 50 & 3.45 \\
9 & 51 & 0.95 & 49 & 1.69 & 43 & 2.72 \\
10 & 28 & 0.94 & 28 & 1.61 & 15 & 2.60 \\
\hline
\end{tabular}

Notes: ${ }^{1}$ (a) $n=4$ years $(2001 \sim 2004) ;{ }^{2}$ (b) $n=8$ years $(2001 \sim 2008) ;{ }^{3}$ (c) $n=12$ years $(2001 \sim 2012)$.

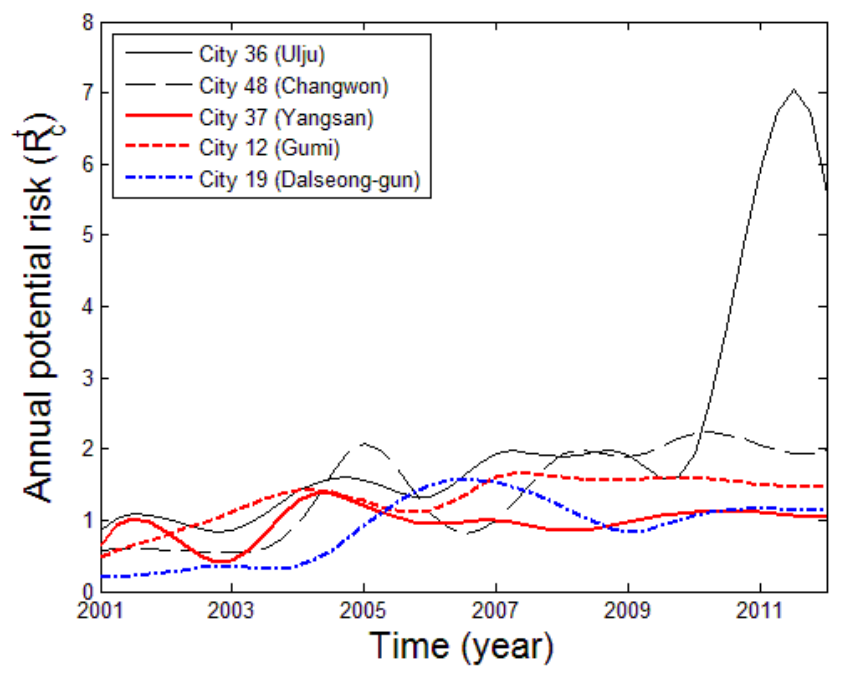

Figure 7. Variation of annual potential risk $\left(R_{c}^{t}\right)$ for five cities in the Nakdong River Basin.

The results of potential risk calculated from these three variables show the usefulness and applicability of PRTR data. Being a voluntary report system, PRTR may have a problem in the accuracy of data. Reports can be found that there are discrepancies between PRTR data and real release data [30-32]. The gap between PRTR and real data generally occurs in all chemicals rather than a specific chemical. Nevertheless, the gap does not affect the results of this study because it is not the potential risk value itself but the rank of a city that matters.

The strength of the present study is the fact that the relative comparison of potential risk between cities is feasible. The rank of potential risk of each city gives specific information to decision-makers by prioritizing the management target. The generality of the potential risk function is another merit of the method developed here. Although the function was demonstrated for an ASTR site in this study, it can be applied to any purification plants. The function can be used for the assessment of potential risk created by both a single chemical and multiple chemicals. Additionally, the potential risk can be assessed either at a specific time or over a certain period of time.

\section{Conclusions}

Based on the assessment result of potential risk due to chemicals transferred in a watershed, it was found that most major hazards of the ASTR site could be eliminated if the chemicals generated in city 36,48 , and 37 are carefully managed. The potential risk was derived from total amount of chemicals transferred in the PRTR database, distance, and toxicity. 
Conventionally, the PRTR has aimed to reduce the amount of chemical release voluntarily through the open access of information. This study, however, showed the feasibility that PRTR data can be used for potential risk assessment. Regarding the distance, the geographic distance between the location of interest and a city turned out to be a reasonable metric, even though it may not represent the detail physical or chemical processes in the watershed.

In most risk assessment practice, toxicity usually represents the degree of harm to human health. As an index of toxicity, Reference Dose for oral exposure (RfD) or Reference Concentration for Inhalation exposure (RfC) of EPA is typically adopted. It must be emphasized that the present study does not directly address the risk to human health. Instead, we deal with potential risk posed by chemicals transferred in a watershed to a drinking water supply facility. For this purpose, the present study adopted NFPA 704 which is included in Material Safety Data Sheet (MSDS) and uses a simple rating system $(0 \sim 4)$ to hazardous substances.

Even if the research was motivated to extend the hazard analysis in the HACCP application to the drinking water supply system using the aquifer storage transfer and recovery process, it is believed that the tool developed here to assess the potential risk caused by chemicals in a basin can find a wide range of application including various water-related facilities.

Acknowledgments: This research was supported by a grant (code 15AWMP-B066761-03) from AWMP Program funded by Ministry of Land, Infrastructure and Transport of Korean government.

Author Contributions: Hyon Wook Ji developed the methodology and conducted the work under the supervision and review of Sang-Il Lee.

Conflicts of Interest: The authors declare no conflict of interest.

\section{References}

1. Cho, S.H.; Lee, Y.J.; Yoon, H.B. Korean's perception and attitudes regarding their tap water (in Korean). Korean Public Health Res. 2006, 32, 130-140.

2. Dillon, P. Future management of aquifer recharge. Hydrogeol. J. 2005, 13, 313-316. [CrossRef]

3. Rahman, M.A.; Rusteberg, B.; Uddin, M.S.; Saada, M.A.; Rabi, A.; Sauter, M. Impact Assessment and Multicriteria Decision Analysis of Alternative Managed Aquifer Recharge Strategies Based on Treated Wastewater in Northern Gaza. Water 2014, 6, 3807-3827. [CrossRef]

4. Sheng, $Z$. An aquifer storage and recovery system with reclaimed wastewater to preserve native groundwater resources in El Paso, Texas. J. Environ. Manag. 2005, 75, 367-377. [CrossRef] [PubMed]

5. Page, D.; Vanderzalm, J.; Miotliński, K.; Barry, K.; Dillon, P.; Lawrie, K.; Brodie, R.S. Determining treatment requirements for turbid river water to avoid clogging of aquifer storage and recovery wells in siliceous alluvium. Water Res. 2014, 66, 99-110. [CrossRef] [PubMed]

6. Havelaar, A.H. Application of HACCP to drinking water supply. Food Control 1994, 5, 145-152. [CrossRef]

7. Jagals, C.; Jagals, P. Application of HACCP principles as a management tool for monitoring and controlling microbiological hazards in water treatment facilities. Water Sci. Technol. 2004, 50, 69-76. [PubMed]

8. Damikouka, I.; Katsiri, A.; Tzia, C. Application of HACCP principles in drinking water treatment. Desalination 2007, 210, 138-145. [CrossRef]

9. Tavasolifar, A.; Bina, B.; Amin, M.M.; Ebrahimi, A.; Jalali, M. Implementation of hazard analysis and critical control points in the drinking water supply system. Int. J. Environ. Health Eng. 2013, 1, 1-7.

10. Lee, S.-I.; Ji, H.W. Identification of Hazardous Events for Drinking Water Production Process using Managed Aquifer Recharge in the Nakdong River Delta, Korea. Malays. J. Anal. Sci. 2016, 20, 365-372.

11. Zio, E. Introduction to the Basics of Reliability and Risk Analysis; World Scientific: Singapore, 2007; pp. 3-10.

12. Benson, S.; Oldenburg, C.; Hoversten, M.; Imbus, S. Carbon Dioxide Capture for Storage in Deep Geologic Formations-Results from the $\mathrm{CO}_{2}$ Capture Project; Elsevier: Amsterdam, The Netherlands, 2005; Volume 2, pp. 1131-1141.

13. Hass, C.N.; Rose, J.B.; Gerba, C.P. Quantitative Microbial Risk Assessment, 2nd ed.; Wiley: Hoboken, NJ, USA, 2014; pp. 63-81.

14. Smeets, P.W.M.H.; Rietveld, L.C.; van Dijk, J.C.; Medema, G.J. Practical applications of quantitative microbial risk assessment (QMRA) for water safety plans. Water Sci. Technol. 2010, 61, 1561-1568. [CrossRef] [PubMed] 
15. Toze, S.; Bekele, E.; Page, D.; Sidhu, J.; Shackleton, M. Use of static Quantitative Microbial Risk Assessment to determine pathogen risks in an unconfined carbonate aquifer used for Managed Aquifer Recharge. Water Res. 2014, 44, 1038-1049. [CrossRef] [PubMed]

16. Bartram, J.; Corrales, L.; Davison, D.; Drury, D.; Gordon, B.; Howard, G.; Rinehold, A.; Stevens, M. Water Safety Plan Manual: Step-by-Step Risk Management for Drinking-Water Suppliers; World Health Organization: Geneva, Switzerland, 2009.

17. Thomas, J.M.; Mckay, W.A.; Cole, E.; Landmeyer, J.E.; Bradley, P.M. The Fate of Haloacetic Acids and Trihalomethanes in an Aquifer Storage and Recovery Program, Las Vegas, Nevada. Groundwater 2000, 38, 605-614. [CrossRef]

18. Ying, G.G.; Kookana, R.S.; Dillon, P. Sorption and degradation of selected five endocrine disrupting chemicals in aquifer material. Water Res. 2003, 37, 3785-3791. [CrossRef]

19. Maeng, S.K.; Sharma, S.K.; Abel, C.D.T.; Magic-Knezev, A.; Amy, G.L. Role of biodegradation in the removal of pharmaceutically active compounds with different bulk organic matter characteristics through managed aquifer recharge: Batch and column studies. Water Res. 2011, 45, 4722-4736. [CrossRef] [PubMed]

20. Lee, J.K.; Kim, T.O.; Jung, Y.J. Analysis of domestic water pollution accident and response management. J. Wetl. Res. 2013, 15, 529-534. (In Korean) [CrossRef]

21. Ito, S.; Yokoyama, T.; Asakura, K. Emissions of mercury and other trace elements from coal-fired power plants in Japan. Sci. Total Environ. 2006, 368, 397-402. [CrossRef] [PubMed]

22. Environmental Protection Agency. Annual Report; Environmental Protection Agency: Washington, DC, USA, 2001.

23. Ministerio del Medio Ambiente. PRTR. Available online: http://www.mma.gob.cl/retc_ingles/1316/w3channel.html (accessed on 01 March 2016).

24. Government of the Netherlands. General Introduction to the Emission Register Project. Available online: http://www.emissieregistratie.nl/erpubliek/content/explanation.en.aspx (accessed on 23 September 2015).

25. PRTR Information System. Annual Report (2013). Available online: http://ncis.nier.go.kr/triopen/ (accessed on 15 March 2015).

26. Sheshinski, R.H. Indirect data collection for waste statistics and waste indicators. Stat. J. U. N. Econ. Commun. Eur. 2002, 19, 53-63.

27. National Fire Protection Association. What is NFPA 704? Available online: http://www.nfpa.org/codesand-standards /document-information-pages?mode=code\&code=704 (accessed on 15 April 2015).

28. Korea Information System for Chemical Safety Management. Available online: http://kischem.nier.go.kr/ kischem2/wsp/main/main.jsp (accessed on 20 March 2015).

29. Nardo, M.; Saisana, M.; Saltelli, A.; Taranta, S. Tools for Composite Indicators Building; European Communities: Ispra (VA), Italy, 2005; pp. 47-48.

30. Lerche, D.; Matsuzaki, S.Y.; Sørensen, P.B.; Carlsen, L.; Nielsen, O.J. Ranking of chemical substances based on the Japanese Pollutant Release and Transfer Register using partial order theory and random linear extensions. Chemosphere 2004, 55, 1005-1025. [CrossRef] [PubMed]

31. Yokouchi, Y.; Inagaki, T.; Yazawa, K.; Tamaru, T. Estimates of ratios of anthropogenic halocarbon emissions from Japan based on aircraft monitoring over Sagami Bay, Japan. J. Geophys. Res. 2005, 110. [CrossRef]

32. Yamagata, H.; Saino, H.; Minamiyama, M.; Takahashi, M. Comprehensive management of chemical substances in a water environment using PRTR data. Water Sci. Technol. 2006, 53, 99-106. [CrossRef] [PubMed]

(C) 2016 by the authors; licensee MDPI, Basel, Switzerland. This article is an open access article distributed under the terms and conditions of the Creative Commons Attribution (CC-BY) license (http://creativecommons.org/licenses/by/4.0/). 